\title{
Pemodelan Elemen Interior untuk Pusat Pendidikan dan Pelatihan bagi Tunarungu di Jakarta
}

\author{
Muhammad Fauzi dan Andi Youna Catherine Bachtiar \\ Jurusan Desain Interior, Fakultas Desain dan Industri Kreatif, Universitas Esa Unggul \\ e-mail: azie.f@esaunggul.ac.id
}

\begin{abstract}
Abstrak-Kebutuhan tuna rungu dalam fasilitas umum yang kurang ideal dari faktor kenyamanan dan keamanan maka hal ini perlu diperhatikan dalam pengembangan fasilitas umum salah satunya berupa tempat sarana pendidikan yang berkaitan dengan Rehabilitasi dan Pendidikan bagi tunarungu di Jakarta banyak yang belum ideal karena terbatasnya manfaat dan fungsi elemen ruang yang disesuaikan dengan fisiknya. Hal ini dapat disebabkan adanya beberapa faktor permasalahan dalam karakteristik tunarungu yang perlu dikaitkan dalam pengembangan elemen interior agar dapat memberi solusi untuk tunarungu dalam beraktifitas secara optimal dan mandiri. Metode penelitian ini menggunakan kualitatif dengan cara pengamatan fenomenologi. Dalam Grounded Theory tidak dikenal adanya hipotesis, akan tetapi diperkenankan sebuah hipotesis kerja yang di deskripsikan sebagai sebuah pernyataan. Hipotesis kerja dalam penelitian ini adalah Pemodelan Elemen Interior Untuk Pusat Pendidikan dan Pelatihan Bagi Tunarungu di Jakarta. Studi Kasus dilaksanakan pada sebuah Sekolah Luar Biasa Pangudi Luhur Jakarta Barat dan Yayasan Rumah Siput Indonesia yang paling dominan terhadap rehabilitasi dan pendidikan Tunarungu sehingga mempermudah eksperimen dan kajian dalam menemukan karakteristik elemen interior yang pada awalnya menggunakan prinsip The Deaf Space Design Guidelines berupa Space and Proximity, Sensory Reach, Mobility and Proximity, Light and Color dan Acoustics. Kesimpulan dalam analisa ini ditemukan sebuah karakteristik elemen interior yang sesuai karakteristik tunarungu hingga dilanjutkan usulan konsep desain interior untuk pusat Rehabilitasi dan Pendidikan Bagi Tunarungu.
\end{abstract}

Kata kunci: pusat pendidikan, karakteristik tunarungu, dan elemen interior

Abstract -- Deaf needs in public facilities that are less than ideal from the comfort and safety factors, so this needs to be considered in the development of public facilities, one of which is an educational facility related to Rehabilitation and Education for deaf people in Jakarta, many of which are not ideal because of the limited benefits and functions of space elements. which is adapted to the physical. This can be caused by several factors in the characteristics of deaf characteristics that need to be linked in the development of interior elements in order to provide solutions for deaf in optimal. This research method uses qualitative methods of phenomenological observation. In a Grounded Theory there is no known hypothesis, but a working hypothesis is allowed which is described as a statement. The working hypothesis in this study is Interior Element Modeling for Deaf Education and Training Centers in Jakarta. The Case Study was conducted at a Pangudi Luhur Special School in West Jakarta and the most dominant Indonesian Snail Foundation for rehabilitation and Deaf education so as to facilitate experimentation and study in finding the characteristics of interior elements which initially used the principle of The Deaf
Space Design Guidelines in the form of Space and Proximity. Sensory Reach, Mobility and Proximity, Light and Color and Acoustics. The conclusion in this analysis found a characteristic of interior elements that matched the characteristics of the deaf and continued the proposed concept of interior design for Rehabilitation and Education centers for the Deaf.

Keywords: education center, deaf characteristics, and interior element.

\section{PENDAHULUAN}

Kebutuhan tuna rungu dalam fasilitas umum yang kurang mendukung dan memadai. Fasilitas umum berupa tempat sarana transportasi, pendidikan, kesehatan dan tempat-tempat umum yang berkaitan dengan rehabilitasi bagi tunarungu yang belum ideal karena terbatasnya manfaat ruang yang disesuaikan dengan fisiknya. Hal ini dapat disebabkan adanya beberapa problematik dalam komunikasi yang sulit dan perlu diatasi sehingga perlu adanya fasilitas berupa elemen interior yang ideal sehingga mudah terbantu dalam beraktifitas secara optimal dan mandiri.tunarungu adalah seseorang yang mengalami kekurangan atau kehilangan kemampuan mendengar baik sebagian atau seluruhnya yang diakibatkan oleh tidak fungsinya sebagian atau seluruh alat pendengaran, sehingga anak tersebut tidak dapat menggunakan alat pendengarannya dalam kehidupan sehari-hari. Hal tersebut berdampak terhadap kehidupannya secara kompleks terutama pada kemampuan berbahasa sebagai alat komunikasi yang sangat penting. Gangguan mendengar yang dialami anak tunarungu menyebabkan terhambatnya perkebangan bahasa anak, karena perkembangan tersebut, sangat penting untuk berkomunikasi dengan orang lain. Berkomunikasi dengan orang lain membutuhkan bahasa dengan artikulasi atau ucapan yang jelas sehingga pesan yang akan disampaikan dapat tersapaikan dengan baik dan mempunyai satu makna, sehingga tidak ada salah tafsir makna yang dikomunikasikan. Dalam Penelitian ini tertuju untuk pendidikan dan rehabilitasi bagi tunarungu yang perlu di realisasikan karena temuan ini sangat mempengaruhi bagi tunarungu dalam berkomunikasi maupun beraktifitas secara mandiri.

Penelitian ini diharapkan dapat menemukan karakteristik elemen interior yang tepat bagi tunarungu dalam beraktifitas khususnya dalam interior yang terkait dengan aktifitas komunikasi dan perilakunya. Metode yang dilakukan dengan cara pengamatan fenomenologis pada atmosfer ruangan pusat pendidikan dan rehabilitasi tuna rungu di Jakarta dan cara-cara pendekatan psikologi. Dalam penelitian ini tertuju pada karakteristik elemen interior yang tidak hanya dengan pendekatan estetis saja melainkan pendekatan psikologis atau karakter penghuninya, maka oleh karena itu penelitian ini sebagai inovasi berpikir dalam menentukan bahan dalam perancangan interior maupun arsitektur. Sasaran desain yang ingin dicapai secara keseluruhan membuat 
Tabel 1. Penjabaran Kriteria Bahan dengan pendekatan space and proximity.

\begin{tabular}{|c|c|c|c|c|}
\hline Ruang & $\begin{array}{c}\text { Kriteria } \\
\text { Lantai dan Alternatif Bahan }\end{array}$ & $\begin{array}{c}\text { Kriteria } \\
\text { Ceiling dan Alternatif Bahan }\end{array}$ & $\begin{array}{c}\text { Kriteria } \\
\text { Dinding dan Alternatif Bahan }\end{array}$ & Keterangan \\
\hline $\begin{array}{l}\text { Ruang Kelas, Ruang } \\
\text { laboratori-um komputer, } \\
\text { Ruang Terapi Wicara dan } \\
\text { Keteram-pilan }\end{array}$ & $\begin{array}{l}\text { - Kuat Menahan Beban } \\
\text { - Tidak Licin } \\
\text { - Mudah dalam perawatan dan } \\
\text { pembersihan } \\
\text { - Pola Lantai Tidak Rumit, di } \\
\text { usahakan lebih monoton } \\
\text { Alternatif Bahan } \\
\text { Lantai Kayu Solid Wood } \\
\text { Flooring dengan Pola Lurus }\end{array}$ & $\begin{array}{l}\text { - Tahan Panas dan Mudah } \\
\text { Perawatan } \\
\text { - Tidak Terlalu menonjol } \\
\text { dalam aspek bentuk namun } \\
\text { memberi daya Tarik estetika } \\
\text { pada terapan pencahayaan } \\
\text { buatan } \\
\text { - Tinggi Ceiling diutamakan } \\
\text { lebih dari > } 4 \text { M. } \\
\text { Alternatif Bahan } \\
\text { Gypsum Board, dan Panel } \\
\text { Aluminium }\end{array}$ & $\begin{array}{l}\text { - } \text { Terbuka dan transparan } \\
\text { namun tidak terlalu } \\
\text { menyilaukan dari } \\
\text { pencahayaan alami } \\
\text { - Tahan Air dan Tidak Mudah } \\
\text { Kotor } \\
\text { - Tahan terhadap gesekan, } \\
\text { aman dan nyaman } \\
\text { - Disarankan tidak diterapka } \\
\text { motif atau aksen pada dindin } \\
\\
\text { Alternatif Bahan } \\
\text { Dinding Bata Plester Finishing } \\
\text { Tembok, Aluminium pada } \\
\text { Kusen Jendela dan Kaca Akrilik } \\
\text { Bening 10mm, Kayu Plywood } \\
\text { untuk aksen pada dinding }\end{array}$ & $\begin{array}{l}\text { Pada Lantai disesuaikan dengan } \\
\text { tema dan karakteristik tunarungu } \\
\text { pada dalam pemilihan warna kayu } \\
\text { yang terkesan luas dan tidak mudah } \\
\text { membosan-kan. } \\
\text { Pada Ceiling menggunakan elemen } \\
\text { material yang sederhana karena } \\
\text { diusahakan tidak lebih menonjol } \\
\text { disbanding-kan elemen interior } \\
\text { lainnya. } \\
\text { Pada Dinding disesuaikan } \\
\text { keterbukaan, kuat dan estetis hingga } \\
\text { suasana ruang lebih nyaman dan } \\
\text { aman bagi tunarungu }\end{array}$ \\
\hline
\end{tabular}

bagian-bagian elemen interior kedalam perencanaan desain interior pusat rehabiltasi dan pendidikan bagi tunarungu dengan memperhatikan aspek-aspek karakteristik bagi penggunanya dengan menerapkan standarisasi yang ada. Ruang lingkup dari penelitian ini ditujukan pada ranah perancangan desain interior yang berdasarkan penelitian (Design by Research).Area dalam penelitian ini memasuki ranah penelitian di bidang Seni rupa dan Desain yang mempertautan disiplin ilmu desain interior dengan desain produk.Dengan demikian penelitian ini sangat berkontribusi dalam pengembangan Industri Kreatif di Indonesia serta sekaligus bermanfaat untuk pembangunan interior maupun arsitektur dengan rasa yang adil bagi kemanusiaan dan menjadikan bangsa Indonesia yang dikagumi dunia khususnya dalam seni rupa dan desain.

Penelitian yang diterapkan oleh tentang karakteristik yang dimiliki oleh seorang penyandang cacat tunarungu berbeda dengan orang normal [1]. Kekurangan mereka dalam indera pendengaran menyebabkan mereka kesulitan dalam bersekolah dan kesulitan dalam mencari pekerjaan. Di Kota Manado, para penyandang cacat tunarungu hanya bersekolah dengan menumpang di sekolahsekolah luar biasa yang lain. Hal ini dapat menyebabkan kurang efektifnya sistem pembelajaran bagi anak-anak penyandang cacat tunarungu.Untuk itulah sangat dibutuhkan sarana dan prasarana yang memadai guna untuk mencerdaskan anak-anak penyandang cacat tunarungu. Perancangan Sekolah Luar Biasa bagian B di Manado sangat dibutuhkan oleh anak-anak tunarungu dengan memakai tema "arsitektur bagi penyandang cacat tunarungu, mata yang mendengar" bertujuan untuk merancang Sekolah Luar Biasa bagian B yang didalamnya mereka tidak saja menuntut ilmu, tapi juga dapat melatih diri mereka sendiri agar ketika berada di dunia luar, mereka tidak dianggap rendah oleh orang-orang normal.

Penelitian yang dilakukan menerapkan penelitian tentang fasilitas publik untuk tunanetra yang dijadikan sebagai bahan pertimbangkan bagi penyandang cacat lainnya, dengan berjudul pusat pengembangan kreatifitas anak tunanetra.Tunanetra merupakan suatu kondisi dimana mata mengalami kekurangan daya dalam melihat. Di Indonesia, kebutuhan anak-anak tunanetra untuk mendapatkan perlakuan seperti halnya dengan anak - anak yang normal kurang begitu diperhatikan. Hal ini menandakan bahwa dibutuhkannya suatu fasilitas yang dapat membantu proses pengembangan kreativitas anak - anak tersebut agar tidak dipandang sebelah mata. Fasilitas tersebut adalah Pusat Pengembangan Kreativitas Anak Tunanetra yang merupakan salah satu fasilitas publik sebagai jawaban atas masih sedikitnya fasilitas yang mampu mewadahi aktivitas bakat dan minat anak tunanetra.Fasilitas ini diharapkan dapat memberikan kenyamanan untuk beraktivitas dan dapat mendukung interaksi sosial antara anak - anak tersebut, keluarga dan masyarakat awam. Penelitian yang diterapkan tentangPerkembangan fisik yang menyimpang pada anak tunanetra akan menghambat penyesuaian diri pada anak tersebut. Gangguan yang ada menyebabkan anak tunanetra memiliki keterbatasan dalam mobilitas dan orientasi. Mobilitas dan orientasi menjadi kebutuhan utama anak tunanetra karena berkaitan dengan kemampuan bergerak anak dari satu tempat ke tempat lain. Mobilitas dan orientasi sebaiknya ditangani sejak dini dan didapatkan melalui pendidikan di taman kanak-kanak. Sebagai tempat belajar utama siswa, ruang kelas dapat berperan sebagai media latih mobilitas dan orientasi [2] dan [3].

Perancangan ruang kelas didasari analisa anak tunanetra pada masing-masing klasifikasi serta analisa mobilitas dan orientasi, sehingga didapatkan kriteria perancangan ruang kelas.Penerapan kriteria perancangan ruang kelas berdasarkan hasil analisa anak tunanetra terkait mobilitas dan orientasi, dilakukan untuk mendapatkan perancangan ruang kelas yang dapat mendukung mobilitas dan orientasi siswa.

Dalam penjelasan penelitian sebelumnya diatas, maka pada Penelitian ini, yang memfokuskan pada konsep perancangan karakteristik elemen interior pusat rehabilitasi tunarungu di Jakarta belum ditemukan sehingga Penelitian ini memiliki keunikan sebagai studi [4] dan [5].

\section{METODE}

Lokasi penelitian yang dapat diterapkan perancangan Elemen Interior pusat rehabilitasi tunarungu di Jakarta yang paling dominan menggunakan sign language dan oral speak yaitu di SLB-B Pangudi Luhur Jakarta yang terletak di Jalan Kencana Murni No.125, RT.2/RW.6, Kembangan Selatan, RT.2/RW.7, Kembangan Sel., Kembangan, Kota Jakarta Barat, Daerah Khusus Ibukota Jakarta 11610 dan Yayasan Rumah Siput Indonesia (YRSI) yang merupakan yayasan yang berdiri agar anak-anak yang mengalami gangguan pendengaran atau tunarungu, bisa diperiksa dan didiagnosa secara dini, lalu diberikan intervensi yang bertujuan agar penyandang tunarungu tidak mengalami keterlambatan dalam berkomunikasi. Yayasan ini terletak di Jl. Pertanian V. Cilandak Jakarta Selatan.

Atas dasar pertimbangan kompleksitas penelitian yang akan dihadapi karena permasalahan yang berkaitan dengan pencarian rumusan masalah serta penyelesaian desain, maka metode penelitian yang paling tepat dipilih metode penelitian kualitatif, dengan memilih strategi penelitian Grouded Theory. Strategi yang dipilih didasarkan pada pertimbangan keleluasaan dalam meneliti, yaitu secara induktif, sehingga data yang terhimpun dapat diperkaya sebagai solusi perancangan.

Adapun metode pengamatannya dilakukan secara fenomenologi, yaitu, fenomenologi ditujukan untuk membimbing penelitian di ranah desain termasuk arsitektur dan interior dilalui secara mendalam bersandar intuisi dan intelektualitas peneliti. Fenomenologi sebagai a way of looking at things bagi gejala yang menampilkan diri untuk dilukiskan melalui tesis intensionalisme. Untuk memahami permasalahan interior pusat rehabilitasi tunarungu, dilakukan dengan mengalami keruangan secara langsung dari segala arah yang memungkinkan. Merujuk 
Tabel 2. Penjabaran kriteria bahan dengan pendekatan sensory reach

\begin{tabular}{|c|c|c|c|c|}
\hline Ruang & $\begin{array}{c}\text { Kriteria } \\
\text { Lantai dan Alternatif Bahan }\end{array}$ & $\begin{array}{c}\text { Kriteria } \\
\text { Ceiling dan Alternatif Bahan }\end{array}$ & $\begin{array}{c}\text { Kriteria } \\
\text { Dinding dan Alternatif Bahan }\end{array}$ & Keterangan \\
\hline $\begin{array}{l}\text { Ruang Kelas, Ruang } \\
\text { laboratorium komputer, } \\
\text { Ruang Terapi Wicara dan } \\
\text { Keteram-pilan }\end{array}$ & $\begin{array}{l}\text { - Lantai dapat diberi akses } \\
\text { signage berupa sticker vinyl } \\
\text { - Lapisan lantai yang mudah } \\
\text { menyerap cahaya contohnya } \\
\text { lebih gloss } \\
\text { Alternatif Bahan } \\
\text { - Vinyl Floor Sticker } \\
\text { - Jenis lntai kayu white oak }\end{array}$ & $\begin{array}{l}\text { - Ceiling dapat dikitkan pada } \\
\text { lantai yaitu diberi signage } \\
\text { darurat berupa sticker vinyl } \\
\text { - Warna dan ukuran pada } \\
\text { signage untuk ceiling } \\
\text { disesuaikan tingginya plafon } \\
\text { agar ergonomis pada sudut } \\
\text { pandang dapat dibaca } \\
\text { dengan baik } \\
\text { - Tinggi Ceiling diutamakan } \\
\text { lebih dari }>4 \mathrm{M} \text {. } \\
\text { Alternatif Bahan } \\
\text { - Vinyl }\end{array}$ & $\begin{array}{l}\text { - Kaca transparan maupun } \\
\text { tidak transparan } \\
\text { - Dilengkapi signage dengan } \\
\text { sticker } \\
\text { - List aluminium dengan } \\
\text { warna cerah } \\
\text { - Desain pada dinding dapat } \\
\text { diberi kaca sedemikian rupa } \\
\text { agar mudah memberi respon } \\
\text { satu sama lain } \\
\text { Alternatif Bahan } \\
\text { - Vinyl Glass }\end{array}$ & $\begin{array}{l}\text { Sensory reach sangat berpengaruh } \\
\text { pada respon terhadap satu sama lain } \\
\text { pada suatu ruangan, maka material } \\
\text { ditentukn yang mudah memberi } \\
\text { respon berupa efek pantulan, } \\
\text { cermin, maupun kilat cahaya }\end{array}$ \\
\hline
\end{tabular}

Ponty tentang penghadiran ke dunia, tidak lain melalui tubuh dengan tindak motorik dan persepsi, oleh Brower disebutkan atasbawah, kanan-kiri, dan muka-belakang dari tubuh kita, termasuk pengalaman rendah dan tinggi dalam pengamatan fenomenologi. Cara pengamatan yang demikian dilalui untuk mencapai rigorous pengamatan cermat yang bersandar kepekaan pancaindera yang berhubungan langsung dengan obyek yang tampil melalui; ketajaman melihat, ketajaman mengecap dengan lidah, ketajaman membaui, ketajaman mendengar, kepekaan meraba melalui kulit. Dalam Grouded Theory, tidak dikenal adanya Hipotesis, akan tetapi diperkenankan sebuah Hipotesis Kerja yang dideskripsikan sebagai sebuah pernyataan. Hipotesis Kerja dalam penelitian ini adalah : Karakteristik elemen Interior Pusat Rehabilitasi dan Pendidikan Bagi Kaum Tunarungu di Jakarta.

Untuk dapat merancang elemen interior yang ideal bagi tunarungu perlu adanya pengamatan fenomenologi yang baik dan studi pembanding dari literatur maupun studi lapangan yang berkaitan dengan obyek yang dirancang. Berdasarkan Kajian literatur dapat disimpulkan bahwa desain untuk tunarungu difokuskan pada kemudahan komunikasi terhadap satu sama lain yang terhambat dari elemen interior seperti partisi padat dan signage lainnya. Pemilihan dalam prinsip-prinsip desain interior perlu adanya pertimbangan agar tidak menganggu psikologis.

Pendekatan yang dipakai adalah pendekatan dengan fenomena pada ruangan disertai psikologis terhadap tunarungu dalam beaktivitas.Dari hasil analisa diatas maka dapat disimpulkan sistem elemen material yang dipakai adalah sistem elemen interior yang dapat mempermudah komunikasi bagi tunarungu seperti efek cermin, transparan, dan sebagainya yang berkaitan dengan sign language.

\section{HASIL DAN PEMBAHASAN}

Pemilihan sekolah yang akan dirancang dari 2 tempat survey yaitu SLB-B Pangudi Luhur dan Yayasan Pendidikan Rumah Siput Indonesia adalah SLB-B Pangudi Luhur, SLB ini dipilih karena sekolah ini tergolong memprihatinkan dari aspek-aspek pada permasalahan interior, dimana anak berkebutuhan khusus di sana tidak mendapatkan pendidikan sesuai dengan kebutuhan mereka dan atmosif yang dialami terasa kurang nyaman.

Dasar dari segala usulan konsep Elemen Interior dikemukakan melalui pengamatan dan eksplorasi dalam menemukan solusi permasalahan yang diangkat sebelumnya.Kesimpulan pada studi kasus ditemukan bahwa belum adanya elemen interior yang ideal dan sesuai dengan karakteristik Tunarungu, maka penelitian ini memiliki peluang untuk mencapai titik temu pada permasalahan elemen ruang untuk Tunarungu yang ideal.

\section{Hasil penelitian analisis karakteristik psikologis tunarungu}

Karakteristik Anak Tunarungu dalam pengamatan langsung pada studi kasus dan hasil kesimpulan wawancara dengan Kepala Sekolah SLB-B Pangudi Luhur Jakarta. Bila diperhatikan anak tunarungu dengan anak normal lainnya tidak jauh berbeda secara signifikan. Tetapi bila diajak berbicara maka terdapat kejanggalan dan kesulitan dalam menyampaikan komunikasi, maka oleh karena itu Tunarungu memiliki karakateristik yang khas dengan cara komunikasi yang berbeda dengan orang normal pada umumnya. Dibawah ini terdapat beberapa aspek yang berkaitan karakteristik tunarungu antara lain :

\section{Aspek intelegansi}

Tunarungu memiliki intelegansi normal dan rata-rata berkembang seperti orang nomal namun tampaknya intelegensi rendah disebabkan karena kesulitan memahami sebuah Bahasa maupun komunikasi maka perkembangan anak tunarungu dengan anak normal lainnya tidak sama cepatnya dengan mereka mendengar karena dengan system pendengaran mereka akan dapat membuat berpikir dan mensimulasikan perkembangan pada otak. Rendahnya inteligensi anak tunarungu bukan disebabkan IQ potensialnya yang tidak berkembang, tetapi fungsinya kurang memperoleh kesempatan untuk berkembang. Aspek inteligensi yang terhambat hanya yang bersifat verbal, misalnya dalam memberikan makna, menarik kesimpulan dan meramalkan suatu kejadian.

\section{Aspek komunikasi}

Perkembangan bahasa bicara anak tunarungu sampai kegiatan alami, dalam upaya melatih pernapasan dan pita suara.Bahasa bagi anak tunarungu.dengan melalui latihan maka bahasa bicaranya diharapkan dapat berkembang. Bahwa perlu dipahami dengan ketidakmampuannya berbahasa dan bicara dibandingkan dengan anak normal akan tampak lebih tertinggal. Hal ini dapat disadari bahwa anak tuarungu di didik khusus tetap saja mengalami waktu yang lebih lama dibandingkan anak normal lainnya seperti di usia 4 - 5 tahun setara dengan anak normal usia 2 tahun. Untuk itu kita mengharapkan dalam pengembangan potensi berkomunikasi perlu adanya kerjasama agar didalam berinteraksi dengan lingkungan dimana anak turungu berada dapat berjalan dengan baik.

\section{Aspek sosial anak tunarungu}

Lingkungan sosial yang diharapkan adalah yang mengerti dan memahami keadaan dan kemampuan anak tunarungu terutama dalam hal berkomunikasi. Kurangnya pengertian terhadap keberadaan anak menyebabkan timbulnya sikap-sikap negatif seperti pembullyan dan lainnya, hal-hal ini merupakan akibat eksternal dari fisik yang dialami dam dapat mengakibatkan terasing dari pergaulan sehari-hari, yang berarti mereka terasing dari pergaulan atau aturan sosial yang berlaku dalam masyarakat dimana ia hidup. Akibat dari keterasingan tersebut dapat menimbulkan efek-efek negatif seperti : egosentrisme, minder, ketergantungan terhadap orang lain, dan lebih mudah tersinggung dan cepat marah.

\section{Analisa karakteristik dengan pendekatan the deaf space design guidelines}

Analisa dikaitkan dengan Karakteristik Psikologi tunarungu yang dijelaskan dalam pengamatan di studi Kasus SLB-B Pangudi 
Tabel 3. Penjabaran Kriteria Bahan dengan pendekatan Mobility and Proximity

\begin{tabular}{|c|c|c|c|c|}
\hline Ruang & $\begin{array}{c}\text { Kriteria } \\
\text { Lantai dan Alternatif Bahan }\end{array}$ & $\begin{array}{c}\text { Kriteria } \\
\text { Ceiling dan Alternatif Bahan }\end{array}$ & $\begin{array}{c}\text { Kriteria } \\
\text { Dinding dan Alternatif Bahan }\end{array}$ & Keterangan \\
\hline $\begin{array}{l}\text { Ruang Kelas, Ruang } \\
\text { laboratorium komputer, } \\
\text { Ruang Terapi Wicara dan } \\
\text { Keteram-pilan }\end{array}$ & $\begin{array}{l}\text { - Lantai diberi perbedaan } \\
\text { tingkat rendahnya atau diberi } \\
\text { aksen untuk menentukan tata } \\
\text { letak furniture agar jarak } \\
\text { sirkulasi dapat ditetapkan } \\
\text { sesuai standarnya Lapisan } \\
\text { lantai yang mudah menyerap } \\
\text { cahaya contohnya lebih gloss } \\
\\
\text { Alternatif Bahan } \\
\text { - Vynil Floor Sticker } \\
\text { - Jenis Lantai Kayu White Oak } \\
\text { Vinyl Floor Sticker } \\
\text { - Jenis lntai kayu white oak }\end{array}$ & $\begin{array}{l}\text { Keseluruhan ceiling yang } \\
\text { tidak terlalu menonjol dan } \\
\text { pencahayaan buatan yang } \\
\text { diterapkan di ceiling } \\
\text { disesuaikan dengan } \\
\text { sirkulasi ruangan. } \\
\text { Alternatif Bahan } \\
\text { - Cat DOF pada Plafon dan } \\
\text { tidak mudah pantul. } \\
\text { - LED Lighting direct Light } \\
\text { dengan Eyeball Down Spot }\end{array}$ & $\begin{array}{l}\text { Perabotan dan furniture } \\
\text { yang diterapkan di dinding } \\
\text { diusahakan lebih minimalis } \\
\text { dan jumlah yang sedikit } \\
\text { agar ruangan tidak terkesan } \\
\text { penuh. } \\
\text { Alternatif Bahan } \\
\text { Warna perabotan dan furniture } \\
\text { di sejajarkan dengan dinding. }\end{array}$ & $\begin{array}{l}\text { Hubungan elemen interior pada } \\
\text { mobility sangat berpengaruh dengan } \\
\text { emosional tunarungu. Jarak benda } \\
\text { dengan manusia di pertimbangkan } \\
\text { adanya ergonomic yang baik } \\
\text { maupun kesan yang tidak } \\
\text { menggangu suasana. }\end{array}$ \\
\hline
\end{tabular}

Tabel 4. Penjabaran Kriteria Bahan dengan pendekatan Light \& Color.

\begin{tabular}{|c|c|c|c|c|}
\hline Ruang & $\begin{array}{c}\text { Kriteria } \\
\text { Lantai dan Alternatif Bahan }\end{array}$ & $\begin{array}{c}\text { Kriteria } \\
\text { Ceiling dan Alternatif Bahan }\end{array}$ & $\begin{array}{c}\text { Kriteria } \\
\text { Dinding dan Alternatif Bahan }\end{array}$ & Keterangan \\
\hline $\begin{array}{l}\text { Ruang Kelas, Ruang } \\
\text { laboratorium komputer, } \\
\text { Ruang Terapi Wicara dan } \\
\text { Keteram-pilan }\end{array}$ & $\begin{array}{l}\text { - Kriteria warna pada lantai } \\
\text { yang netral agar dapat } \\
\text { menyerap cahaya signal. } \\
\text { - Warna lantai tidak terlalu } \\
\text { gelap dan didominasi warna } \\
\text { netral. } \\
\text { Alternatif Bahan } \\
\text { - Vynil Floor Sticker } \\
\text { - Jenis Lantai Kayu White Oak }\end{array}$ & $\begin{array}{l}\text { - Kriteria Warna Pada Ceiling } \\
\text { diutamakan lebih gelap } \\
\text { dibanding-kan dinding. } \\
\text { - Pencahayaan pada ceiling } \\
\text { tidak menyebar. Cahaya lebih } \\
\text { dominan mengguna-kan } \\
\text { direct light } \\
\text { Alternatif Bahan } \\
\text { - Cat DOF pada Plafon dan } \\
\text { tidak mudah pantul. } \\
\text { - LED Lighting direct Light } \\
\text { dengan Eyeball Down Spot }\end{array}$ & $\begin{array}{l}\text { Warna pada dinding lebih } \\
\text { netral dan Lapisan kasar agar } \\
\text { pantulan pencahayaan tidak } \\
\text { terlalu menyilaukan } \\
\text { Alternatif Bahan } \\
\text { Warna Netral } \\
\text { Abu-abu, Hijau Muda, Biru } \\
\text { Muda dan Kombinasi Hitam. }\end{array}$ & $\begin{array}{l}\text { Warna dan Cahaya adalah peran } \\
\text { penting dalam atmosfir pada } \\
\text { interior. }\end{array}$ \\
\hline
\end{tabular}

Luhur dengan pertimbangan pada Elemen Interior yang ditentukan untuk mencapai karakteristik yang ideal antara lain :

\section{a. Space and proximity}

Pada Tabel 1, dijelaskan maksud dari prinsip psikologi terhadap karakteristik tunarungu space and proximity adalah membentuk ruang yang nyaman bagi penyandang tunarungu untuk beraktivitas. Pada faktor kemampuan Bahasa dan Komunikasi yang dijelaskan bahwa seringkali penyandang tunarungu membutuhkan kemampuan visualitasnya dalam berkomunikasi.Tunarungu lebih dominan dengan karakteristik face to face agar lebih mudah memahami dalam peyampaian pesan melalui oral maupun sign language.

Bentuk Ruangan yang di usulkan melalui pertimbangan dari psikilogis karakteristik tunarungu seperti menyerupai lingkaran agar lebih fleksibel dan leluasa dalam memandang sesama.Bentuk dasar yang diterapkan pada sekolah SLB-B Pangudi Luhur lebih dominan dengan bentuk lingkaran yang di aplikasikan pada ruangan kelas, furniture dan sebagainya dengan fungsi yang digunakan bagi penyandang tunarungu. Nilai positif dalam bentuk Lingkaran dapat membantu pada psikologis tunarungu terutama kelelahan dalam aktifitas komunikasi satu sama lain.

\section{b. Sensory reach}

Pada Tabel 2, karakteristik psikologi tunarungu ini diterapkan untuk dapat membantu atau bahkan meningkatkan rangsangan indera yang dimiliki panyandang tunarungu. Dengan menggunakan indera lainnya Siswa tunarungu diharapkan dapat membaca situasi lainnya melalui visual-visual yang ada. Misalnya pada elemen dinding menggunakan aksen kaca transparan pada dipintu agar siswa yang berada didalam kelas dapat mengetahui jika ada orang di depan pintu, penambahan material kaca pada aksen interior agar siswa dapat merespon cepat jika ada panggilan dari belakang. Dalam penggunaan signage di lingkungan sekolah SLB-B Tunarungu dapat diterapkan signage pada umumnya dengan penambahan pencahayaan di beberapa titik agar siswa tunarungu

\section{c. Mobility and proximity}

Karakteristik Tunarungu terdapat pembahasan mengenai cara berkomunikasi dapat dilihat pada Tabel 3. Cara mereka dalam berkomunikasi menggunakan kemampuan visualiasinya sehingga mereka juga tidak terlalu memperhatikan keadaan sekitar bila mereka sudah fokus dalam pembicaraan satu sama lain. Ruangan yang ideal bagi mereka adalah terkesan luas, terbuka dan lebar yang dapat memungkinkan mereka untuk memperhatikan jalan dan lawan bicaranya. Ruang gerak yang dibahas dalam prinsip ini adalah luasan jalan, luasan ruangan kelas, dan akses koridor maupun tangga yang perlu diperhatikan untuk kenyamanan bagi tunarungu.

\section{d. Light and color}

Warna dan cahaya berpengaruh terhadap psikologi tunarungu.Agar mereka dapat melihat dan membaca situasi dengan nyaman, maka warna yang dipilih harus kontras dengan warna kulit.Dengan begitu, siswa tunarungu ketika sedang memperhatikan seseorang berbicara atau berbahasa isyarat. Pemilihan warna interior sekolah Luar Biasa ini lebih dominan terhadap warna netral karena studi kasus tertuju pada anak sma yang rata-rata usianya belasan. Psikologi warna netral dapat dipertimbangan sebagai warna dasar elemen interior yang dipilih sebagai warna karakteristik interior untuk pusat rehabilitasi dan Pendidikan bagi Tunarungu (Tabel 4).

Penjelasan psikilogi warna netral dilampirkan dari sumber pustaka yang kemudian dikembangkan agar dapat disesuaikan karakteristiknya. Pengolahan cahaya yang dibutuhkan ideal menurut Deaf Space design adalah cahaya yang lembut di mata, tidak menyilaukan, dan menghindari ruang yang gelap atau redup. Di sekolah luar biasa tunarungu ini lebih banyak memanfaatkan cahaya langsung dengan dominan cahaya alami pada setiap sudut ruangan. Khusus ruangan kelas diberikan jendela kaca yang besar ddilapisi sticker warna netral agar dapat memaksimalkan pencahayaan langsung.

\section{e. Accoustics}

Pada Tabel 5, dijelaskan bahwa tunarungu memeiliki kesulitan dalam pendengaran maka memerlukan bantuan ruangan yang akustik agar dapat mengkap suara lebih maksimal. Selain itu, dalam penggunaan alat bantu dengar juga memiliki gangguan dan resiko terhadap noise pada ruangan yang menimbulkan gema berlebihan. Sehingga pada interior ini diperlukan adanya pengaturan akustik sesuai kebutuhannya.Pada ruang kelas, auditorium, laboratorium diperlukan aksen dinding yang dapat menerima suara dengan baik untuk di dengar maka diberikan gypsum board pada dinding namun tidak keseluruhan dan tergantung kriteria tema pada perancangan interior. Dan. untuk menghindari gema berlebihan dapat diberikan panel akustik 
Tabel 5 Penjabaran Kriteria Bahan dengan pendekatan Accoustic.

\begin{tabular}{|c|c|c|c|c|}
\hline Ruang & $\begin{array}{c}\text { Kriteria } \\
\text { Lantai dan Alternatif Bahan }\end{array}$ & $\begin{array}{c}\text { Kriteria } \\
\text { Ceiling dan Alternatif Bahan }\end{array}$ & $\begin{array}{c}\text { Kriteria } \\
\text { Dinding dan Alternatif Bahan }\end{array}$ & Keterangan \\
\hline $\begin{array}{l}\text { Ruang Kelas, Ruang } \\
\text { laboratorium komputer, } \\
\text { Ruang Terapi Wicara dan } \\
\text { Keteram-pilan }\end{array}$ & $\begin{array}{l}\text { - Lapisan Lantai sebelum } \\
\text { diterapkan lantai kayu diberi } \\
\text { lapisan kayu plywood dan } \\
\text { foam agar getaran lebih } \\
\text { terasa dibandingkan lapisan } \\
\text { keramik atau semen. } \\
\text { Alternatif Bahan } \\
\text { - Foam } \\
\text { - Plywood } \\
\text { - Parquet Oak White }\end{array}$ & $\begin{array}{l}\text { - Untuk menghindari } \\
\text { munculnya gema berlebih } \\
\text { maka diberikan Foam } \\
\text { Acoustic Panel pada plafon. } \\
\text { Alternatif Bahan } \\
\text { - Gypsum } \\
\text { - Foam Accoustic Panel }\end{array}$ & $\begin{array}{l}\text { - Diberi Aksen Gypsum Board } \\
\text { atau kayu pada dinding } \\
\text { sebagai pemantul suara agar } \\
\text { dapat terdengar oleh } \\
\text { tunarungu. }\end{array}$ & $\begin{array}{l}\text { Pada ruang pelatihan dan } \\
\text { auditorium yang memerlukan } \\
\text { tangkapan suara yang baik untuk } \\
\text { pendengar, }\end{array}$ \\
\hline
\end{tabular}

pada plafon sedangkan ruang terbuka seperti kelas hingga perpustakaan dapat diberikan.Foam akustik panel dan juga penggunaan karpet pada lantai agar dapat mengurangi suara yang bergema. Penjabaran konsep perancangan dari Karakteristik Elemen Interior Pusat Pendidikan Tunarungu yang disederhanakan dalam bentuk tabel dilampirkan jenis aksen yang diterapkan pada elemen-elemen interior dengan pendekatan psikologi Tunarungu. Prinsip-prinsip yang fokus terhadap karakteristik tunarungu sebagai sebuah metode perancangan yang ideal untuk kenyamanan bagi tunarungu dalam menjalani aktifitasnya.

\section{Konsep perancangan elemen ruang}
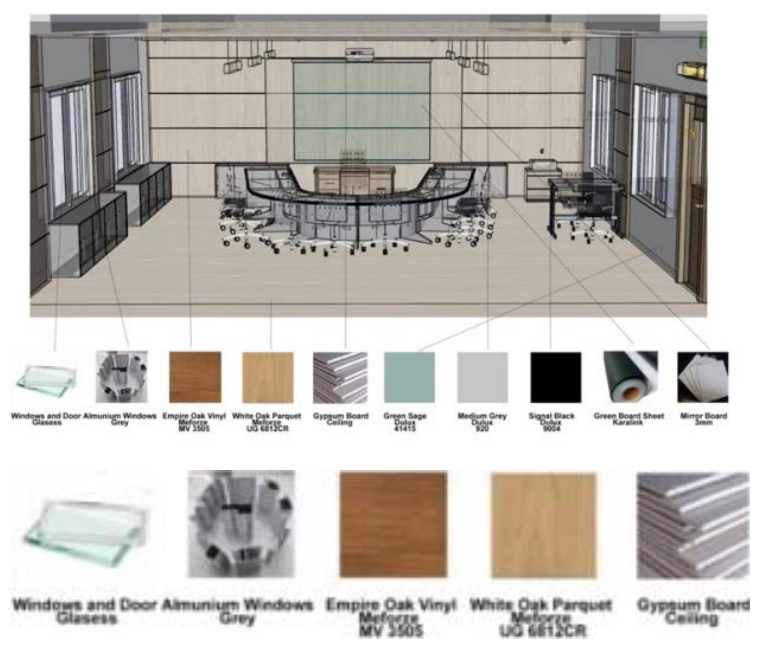
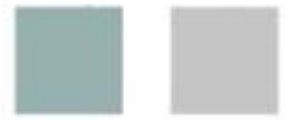

Goreg sope
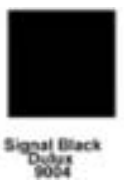

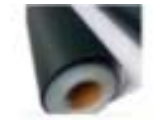

Green Bords sheot

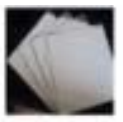

Nimgr Boand
Gambar 1. Skema material pada ruang kelas.

Berdasarkan Gambar 1, umumnya di beberapa Sekolah Luar Biasa untuk tunarungu yang tidak optimal dalam fungsi pada desain interiornya sehingga estetika dan fungsi di dalam ruangan itu terkadang kurang ideal bahkan hilang sama sekali saat ditempatkan oleh siswa yang berada di dalam ruangan. Padahal itu salah satu modal yang besar bagi sekolah untuk menonjolkan fungsinya serta elemen estetisnya.

Secara umum gaya perancangan interior untuk Pusat Pendidikan dan Rehabilitasi Tunarungu yang tepat adalah hasil dari pendekatan perilaku pada interior dengan filosofi "Hearing Visually" dengan konsep kontemporer yang menggabungkan antara konsep masa kini. dan masa depan. Desain ini sesuai dengan kriteria karakteristik tunarungu yang dapat memberikan nuansa hangat dan dingin dalam waktu yang bersamaan. Elemen Interior ini memiliki tampilan yang besih, hampir tidak ada aksen di ruangan dan warnanya netral, bersih dan halus, seperti yang di tampilkan pada Gambar 2.

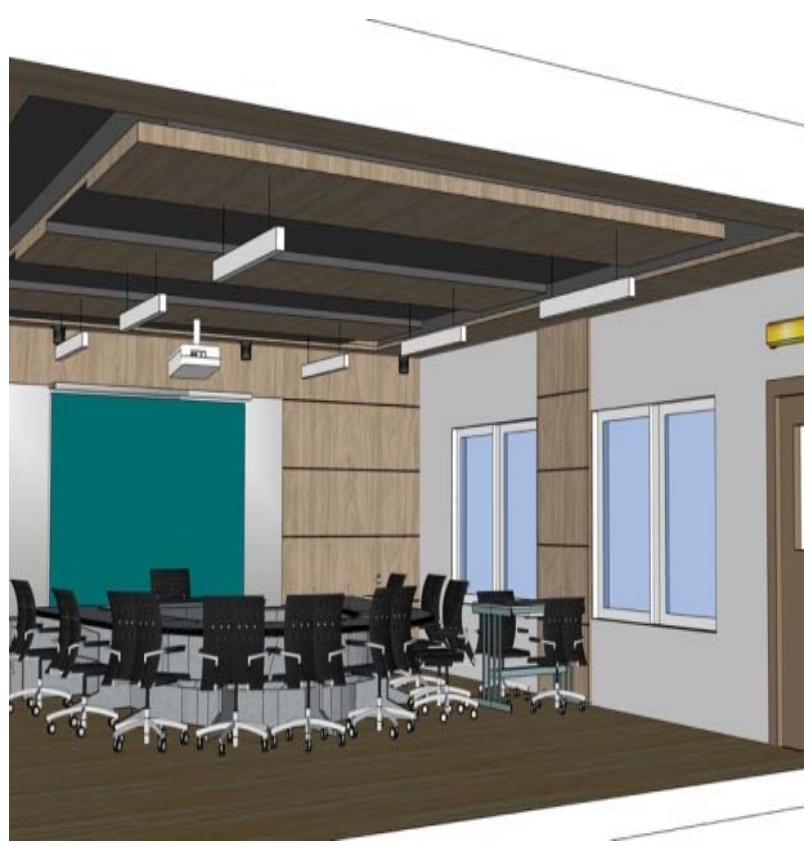

Gambar 2 Hasil 3D ruang kelas pada tampak perspektif.

\section{KESIMPULAN/RINGKASAN}

Berdasarkan Analisis Data di Yayasan Rumah Siput Indonesia dan SLB-B Pangudi Luhur Jakarta dengan pembahasan hasil penelitian yang diuraikan maka dapat diambil kesimpulan bahwa data tinjauan pada lokasi dan eksperimen dari hasil survey penelitian ini menunjukan bahwa belum adanya elemen material pada interior yang ideal. Kesimpulan dalam analisa ini ditemukan sebuah karakteristik elemen interior yang sesuai karakteristik tunarungu dengan pendekatan 5 prinsip Deafspace yaitu space, sensory reach, mobilty, light / colour dan accoustic, pemilihan material lebih dominan dengan aksen kayu pada elemen interior, kelebihan kayu mencakup semua karakteristik seperti menimbulkan getaran, kontras dengan warna kulit yang dikombinasi juga dengan warna cat pilihan, dan pencahayaan buatan dilakukan secara pencahayaan langsung hingga bagian penerangan sangat membantu kesan yang terfokus pada objek maka hal ini dapat membantu tunarungu dalam aktifitas komunikasi satu sama lain yang optimal. Hasil analisa dilanjutkan usulan konsep desain interior untuk pusat Rehabilitasi dan Pendidikan bagi Tunarungu. 


\section{UCAPAN TERIMA KASIH}

Pelaksanaan Penelitian ini tidak terlepas dari kerjasama dan bantuan dari berbagai pihak, oleh karena itu penghargaan dan terima kasih yang setulusnya Tim Peneliti haturkan kepada:

1. Riset dan Pengabdian Masyarakat, Keenterian Riset, Teknologi, dan Pendidikan Tinggi, yang telah memberikan kepercayaan Tugas dan Biaya kepada Tim Peneliti untuk melakukan Penelitian Terapan Unggulan Perguruan Tinggi ini.

2. Kepala Sekolah SLB-B Pangudi Luhur beserta dari Yayasan Rumah Siput Indonesia yang telah berkenan untuk peneliti dalam meninjau ruangan sebagai bahan utama dalam penelitian ini.

\section{DAFTAR PUSTAKA}

[1] Adian, Donny Gahral.Pengantar Fenomenologi. Depok: Penerbit Koekoesan, 2010

[2] Agnes, M. (1999).Webster's New World College Dictionary. New York: Macmillian

[3] Bauman, Hansel. 2016. How Gallaudet University's Architects Are Redefining Deaf Space.

[4] Brouwer, MAW. Psikologi Fenomenologis. Jakarta: PT Gramedia. 1983

[5] Bogdan, Robert C. Dan Steven J. Taylor, Introduction to Qualitative Research Methotds: A Phenomenological Approach in the Social Sciences, alih bahasa Arief Furchan, John Wiley dan Sons, Surabaya,Usaha Nasional. 1992 